\title{
Hervormde Teologiese Kollege Volume, opgedra aan dr. Christo van der Merwe / Reformed Theological College Volume, dedicated to Dr Christo van der Merwe
}

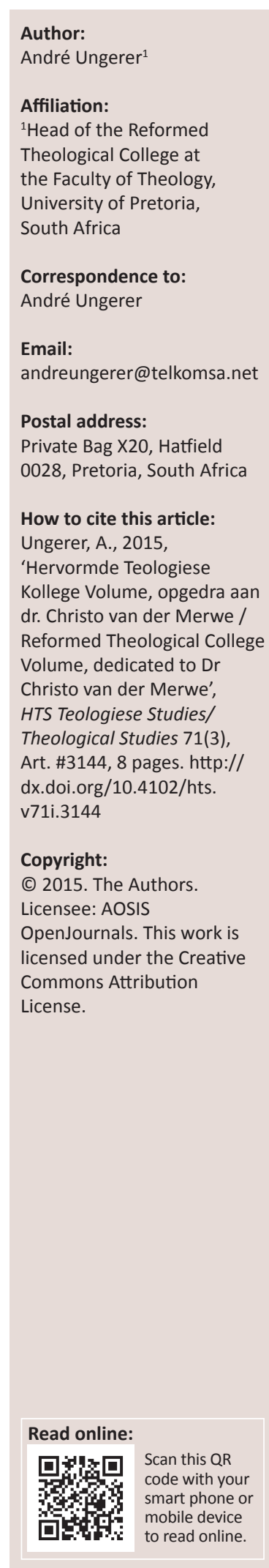

\section{Redaksioneel: Huldiging}

Die eerste predikante wat op eie bodem deur en vir die Nederduitsch Hervormde Kerk van Afrika (NHKA) opgelei is, was J.J. Kuhn en J.J. Prinsloo. Die studeerkamer van dr. P.J. Muller het as 'kweekskool' gedien. Die volle teologiese kurrikulum is onderrig (kyk na Oberholzer 2010:5). Hierdie studente is in 1909 in die Kerk beroepbaar gestel.

In daardie vroeë jare was 'n eie amptelike kweekskool vir baie in die Hervormde Kerk die ideaal. Weens 'n nypende geldtekort was daar egter ook weerstand. Tog het die 34ste Algemene Kerkvergadering (AKV) met 60 stemmeteen 21 opdiestigtingvan'nkweekskool besluit. Dit het egter nie gerealiseer nie en die 36ste AKV besluit op universiteitsopleiding eerder as 'n kweekskool. Hierdie besluit is in 1917 met die stigting van die Fakulteit Teologie aan die Universiteit van Pretoria (UP) tot uitvoer gebring. Dr. J.H.J.A. Greyvenstein is as die eerste Hervormde dosent aangestel. Sedertdien het die 40 dosente van die kerk eers aan studente van die NHKA en later ook aan studente van ander kerke teologiese opleiding gebied. Met die stigting van die Fakulteit was die Presbiteriaanse Kerk ' $n$ vennoot, maar het na 5 jaar onttrek en elders 'n heenkome gevind. Die Nederduitse Gereformeerde Kerk (NGK) het in 1938 deel van die Fakulteit geword. Die Fakulteit is toe verdeel in Afdeling A van die NHKA en Afdeling B van die NG Kerk (Oberholzer 2010:8-14, 41).

Dosente uit al vyf die vakdissiplines was in die beginjare op informele wyse by opleiding in die bedieningspraktyk betrokke. Op 13 Junie 1967 besluit die Kuratorium om 'n sesde leerstoel te skep en dr. J.I. de Wet as dosent in Praktiese Teologie aan te stel. Hy is skielik in 1983 oorlede en is in 1984 deur dr. T.F.J. Dreyer opgevolg.

$\mathrm{Na}$ indringende samesprekings oor rasionalisering by die Universiteit van Pretoria is in Oktober 1998 aan die 65ste AKV verslag gedoen. Vanaf 01 Januarie 2000 sou daar net een multi-kerklike fakulteit wees en die aanstellingprosedures van die Universiteit sou geld. Die bestaande kerklike vennote (NHKA

\section{Editorial: Tribute}

The first ministers trained locally by and for the Netherdutch Rerformed Church of Africa (NRCA) were J.J. Kuhn and J.J. Prinsloo. The study of Dr P.J. Muller served as the seminary'. The full theological curriculum was taught (see Oberholzer 2010:5). These students were licensed in 1909.

In those days, the establishment of an own official seminary was the ideal for many, though not all, in the NRCA. Due to a shortage of funds, there was some resistance to the idea. Though a resolution for the establishment of a seminary was passed with 60 votes against 21 at the 34th General Assembly, nothing came of it. The 36th General Assembly voted for university training rather than a seminary. In 1917, a Faculty of Theology was established at the University of Pretoria (UP), and Dr J.H.J.A. Greyvenstein was the first lecturer appointed by the NRCA. Since then, the 40 lecturers of the church trained at first only students of the NRCA and later also students of other church partners. When the Faculty was first established, the Presbyterian Church was a partner, but after 5 years, it moved its training elsewhere. The Dutch Reformed Church (DRC) joined the Faculty in 1938. Section A of the Faculty of Theology was dedicated to training ministers for the NRCA and Section B for the DRC (Oberholzer 2010:8-14, 41).

During the early days, the lecturers in all five of the theological disciplines participated informally in the practical training of the students. On 13 June 1967, the Curatory appointed Dr J.I. de Wet in Practical Theology, which became the sixth chair. After his unexpected death in 1983, he was succeeded by Dr T.F.J. Dreyer in 1984.

The report on negotiations regarding rationalisation at the University of Pretoria was discussed by the 65th General Assembly in October 1998. Since 01 January 2000, the Faculty has been a unified multi-church Faculty of Theology, and the University's appointment procedures were followed. The previous church partners (the NRCA and the 
en NGK) het tot 31 Desember 2004 nog betekenisvolle inspraak in die Fakulteit gehad (Oberholzer 2010:164-168). Tydens hierdie AKV is soos volg besluit oor die vestiging van die Hervormde Teologiese Kollege (HTK) aan die Fakulteit:

Op 01 Januarie 2000 vestig die Kerk sy eie Teologiese Kollege wat in 'n geakkrediteerde verhouding met die Universiteit van Pretoria staan, maar wat volledig deur die Kerk beheer, bestuur en bekostig word. Hierdie Teologiese Kollege word aanvanklik bedryf met een voltydse hoof en 'n sekretariële diens. Die dienste van deeltydse dosente wat ook by die Fakulteit kan klas gee, word in die vestigingstyd ingekoop. Die Kuratorium kan besluit om later meer voltydse aanstellings te maak, of die personeel en programme van die Kollege aan te pas soos wat dit tot die Kerk se beste voordeel is. Dosente wat by die Fakulteit aangestel is, kan vanselfsprekend gebruik word om doseerwerk by die Kollege te behartig. Die Hervormde Teologiese Studies (HTS) word ook uit die Kollege beheer en bedryf. (bl. 167)

Op 30 Julie 1999 bevestig die Kommissie van die AKV dat die ooreenkoms met die Universiteit van Pretoria onderteken sal word. Daarmee is Afdelings A en B opgehef en die teologiese fakulteit is vir veelkerklike betrokkenheid oopgestel. Die Hervormde Teologiese Kollege kom op 01 Januarie 2000 tot stand. Op 05 Oktober van die vorige jaar is prof. T.F.J. Dreyer aangewys om as die eerste hoof van die Kollege te dien. Die dienste van spesialiste in die Kerk, soos drs. M.J. du P. Beukes, Y. Dreyer, J.C. van der Merwe, J.A. van Biljon en ds. J. Coetzee, sou in die Fakulteit en Kollege aangewend kon word (Oberholzer 2010:169-172).

Die samewerkingsooreenkoms bepaal dat die HTK verantwoordelik sal wees om:

- in samewerking met die Fakulteit Teologie, teologiese opleiding en vorming aan studente van die Nederduitsch Hervormde Kerk te bied

- geïntegreerd met, en aanvullend tot, die akademiese program, studente vir die kerklike bediening op te lei en te vorm

- kerkspesifieke en kerk-eie modules te doseer waardeur die teologiese etos en identiteit van die Nederduitsch Hervormde Kerk in die opleiding en vorming van studente neerslag sal vind

- voortgesette teologiese opleiding vir predikante aan te bied

- programme en kursusse vir die toerusting van ampsdraers en lidmate aan te bied.

Met ingang 2000 tree die Hervormde Teologiese Kollege (HTK) in werking, met prof. Theuns Dreyer as hoof en me. Adri Goosen as die administratiewe beampte. Die beginjare en ontwikkeling van die HTK word deur prof. Dreyer soos volg beskryf:

In die begin was daardie eerste treë maar wankelrig omdat ons eers moes poog om 'n werklike nis vir die HTK te vind. Die eerste paar jaar was maar'n voortsetting van die ou SVTT (Sentrum vir Voortgesette Teologiese Opleiding) wat deel was van Afdeling A van die vorige teologiese fakulteit. Ons het gou besef dat ons ' $n$ kursus moes moduleer wat sou uitloop op die verwerwing van 'n diploma in kerklike bediening wat as voorwaarde sou geld
DRC) still exerted significant influence until 31 December 2004 (Oberholzer 2010:164-168). The 65th General Assembly also decided to establish the Reformed Theological College (RTC) at the University of Pretoria. It was reported as follows (Oberholzer 2010:167):

On 1 January 2000, the Church established its own Theological College which were to be accredited by the University of Pretoria but managed and funded by the Church. This Theological College were to have a full-time Director and an administrative officer. The services of part-time lecturers were to be contracted. In future, the Curatory could make further full-time appointments and could adapt the personnel requirements and programmes better to suit the Church. The College were to make use of the services of the full-time lecturers of the NRCA appointed in the Faculty. The College were to be home to the journal, the HTS Theological Studies. (p. 167; translation - AVA)

On 30 July 1999, the Commission of the General Assembly confirmed that the agreement with the University had been accepted. The two sections of the Faculty were terminated, and the new multi-church Faculty became open to other partnerships. The RTC was established on 01 January 2000. On 05 October of the previous year, Prof T.F.J. Dreyer was appointed as the first Director of the College. The expertise of specialists in the Church, such as Drs M.J. du P. Beukes, Y. Dreyer, J.C. van der Merwe, J.A. van Biljon and the Rev. J. Coetzee, could be utilized in both the Faculty and the College (Oberholzer 2010:169-172).

The agreement stipulated that the College would take responsibility to:

- provide theological training and formation to the students of the NRCA in cooperation with the Faculty of Theology

- provide training and formation for church ministry, integrated with and supplementary to the academic programme of the Faculty

- include church specific modules which would impart the ethos and identity of the NRCA to the students

- provide continuing education for ministers

- provide lay training programmes and courses.

The RTC was established in 2000 with Prof Theuns Dreyer as Director and Ms Adri Goosen as administrative officer. Prof Dreyer describes the early years and development of the College as follows:

First we had to try and find a niche for the College. For the first few years, it was mostly a continuation of the old Centre for Continuing Theological Education which had been part of Section A of the previous theological faculty. We soon saw the need of a Diploma in Church Ministry which would be a requirement for entering into church ministry. This programme was developed from scratch, and the modules had to be described in detail. The Diploma in Church Ministry was introduced, and lecturers from the church were invited to participate in the tuition. From time to time, the modules were adjusted better to suit the new challenges and realities in the Church. (translation - AVA)

Thanks to the vision and excellent leadership of Prof Dreyer the College developed into an exceptional asset for the 
vir toelating tot die proponentseksamen van die Kerk. Dit het beteken dat die kursus volledig gekurrikuleer moet word en die onderskeie modules van die diploma omskryf moes word. Die onderskeie modules is volledig gekurrikuleer om uiteindelik te lei tot 'n Diploma in Kerklike Bediening, en dosente uit die predikantekorps van die Kerk is versoek om deel te word van die onderrig in die verskillende modules. Van tyd tot tyd is die modules aangepas by nuwe uitdagings en werklikhede waarbinne die Kerk kerk moes wees.

Met die visie en uitnemende leierskap van prof. Dreyer is die HTK tot 'n besondere bate vir die NHKA uitgebou. Die NG Kerk volg vanaf 01 Januarie 2012 'n soortgelyke model. Dr. Christo van der Merwe, wat prof. Theuns Dreyer as hoof opgevolg het, beskryf dit soos volg:

Prof. T.F.J. Dreyer, die eerste hoof van die HTK, het aan die einde van 2011 emeritaat aanvaar. Daar kan kwalik genoeg melding gemaak word van die uitstekende werk van prof. Dreyer sedert die vestiging van die Kollege op 1 Januarie 2000 tot by sy emeritaatsaanvaarding aan die einde van 2011 (en ook daarna in raadgewende hoedanigheid). Die Kerk pluk steeds die vrugte van hierdie model van teologiese opleiding. Die praktyk wat onder leiding van prof. Dreyer gevestig en uitgebou is, het homself bewys as doelmatige praktyk om binne 'n veelkerklike fakulteit nogtans die eie aard van die Kerk se opleiding tot sy reg te laat kom. Die NHKA sal baie moeilik ' $n$ beter bedeling kan beding. Enersyds voldoen dit aan die Kerk se ideaal dat sy predikante aan ' $n$ universiteit opgelei sal word en nie aan ' $n$ kweekskool nie, terwyl die etos van die Kerk andersyds behoue moet bly.

Die eerste verslag oor die werksaamhede van die HTK rapporteer aan die 66ste AKV (Oktober 2001) dat voorsiening gemaak is vir praktykvorming (4 periodes per week) vir elke jaargroep van die derde tot die sesde jaar. Kurrikulering vir die Diploma in Kerklike Bediening (DKB) sou in dieselfde jaar gefinaliseer word. Teleurstelling word uitgespreek oor die swak bywoning van die twee geleenthede vir voortgesette teologiese toerusting (VTT) vir predikante die vorige jaar (slegs 18 predikante in Junie en 35 in November). In 2001 het dit heelwat verbeter, maar in die algemeen bly die bywoning teleurstellend.

Volgens die verslag aan die 67ste AKV is vordering gemaak met die kurrikuleringsproses. Kerkspesifieke modules is geïdentifiseer en sekere modules in Dogmatiek, Kerkgeskiedenis en Kerkreg sou deur dosente van die Hervormde Kerk aangebied word. Wat Praktiese Teologie betref, is die aspekte van die opleiding wat kerk-eie aksente verlang in die program vir die Diploma in Kerklike Bediening opgeneem. In 2002 is modules vir die kerkspesifieke MDiv 200 by die Kollege ingestel. Een die vier modules behels ' $n$ skripsie.

Verslae aan die 68ste tot 70ste AKV's gee blyke van die voortdurende verfyning van die kurrikulum. Die Diploma in Kerklike Bediening bevat tans die volgende modules wat deur Hervormde dosente of vakspesialiste aangebied word:

DKB 300 (3de jaar)

DKB 311 - Gesinsbediening in die NHKA

DKB 332 - Diakonale organe van bystand in die NHKA

DKB 343 - Chemiese afhanklikheid
NRCA. The DRC adopted a similar model from 01 January 2012. Dr Christo van der Merwe, successor to Prof Theuns Dreyer, describes it as follows:

Prof T.F.J. Dreyer, the first Director of the HTK, emeritus since the end of 2011, did excellent work from the establishment of the College on 1 January 2000 until his retirement, and thereafter in an advisory capacity. The Church still reaps the benefits of this model of theological training and formation. The model, developed under his leadership, has proven to be effective for maintaining the distinctive ethos of the Church in ministerial training within a multi-church faculty. The NHKA will not easily find a better alternative. Through this model, the Church retains its ideal of university rather than seminary training, and the ethos of the Church is preserved. (translation - AVA)

According to the first HTK report to the 66th General Assembly (October 2001), practical formation (four periods per week) for each year group from the third to the sixth year had been implemented, and the curriculum for the Diploma in Church Ministry was to be finalised before the end of that year. The number of ministers attending the two continuing education courses during the previous year was disappointing (only 18 in June and 35 in November). In the following year, attendance improved somewhat but remained largely disappointing.

According to the report to the 67th General Assembly, progress had been made with the curriculum process. Church-specific modules had been identified, and modules in Systematic Theology, Church History and Church Polity would be taught by lecturers of the Church. With regard to Practical Theology, the church-specific aspects would be incorporated in the programme of the Diploma in Church Ministry. MDiv 200, introduced in 2002, consisted of four church-specific modules, of which one was the dissertation.

Reports to the 68th to 70th General Assembly reflect the continuing refinement of the curriculum. The Diploma in Church Ministry consists of the following modules taught by lecturers or specialists of the Church:

DKB 300 (3rd year)

DKB 311 - Family Ministry in the NRCA

DKB 332 - Diaconal Service Organs of the NRCA

DKB 343 - Addiction

DKB 344 - Knowledge of the Bible (Old Testament)

DKB 354 - Preaching

DKB 400 (4th year)

DKB 411 - Ministerial Practice in the NRCA

DKB 421 - Knowledge of the Bible (New Testament)

DKB 432 - Ministerial Practice - From Text to Sermon

DKB 442 - The Creeds

DKB 453 - Ministerial Practice - Home Visits

DKB 463 - Knowledge of the Bible (Old Testament)

DKB 463 - Ministerial Practice - Youth Ministry

DKB 474 - Preaching 
DKB 344 - Bybelkennis en vaardigheid (Ou Testament)

DKB 354 - Klaspreke

DKB 400 (4de jaar)

DKB 411 - Bedieningspraktyk in die NHKA

DKB 421 - Bybelkennis en vaardigheid (Nuwe Testament)

DKB 432 - Bedieningspraktyk - Teks na preek

DKB 442 - Belydenisskrifte

DKB 453 - Bedieningspraktyk - Huisbesoek

DKB 463 - Bybelkennis en vaardigheid (Ou Testament)

DKB 463 - Bedieningspraktyk - Jeugbediening

DKB 474 - Klaspreke

DKB 500 (5de jaar)

DKB 511 - Preekstrategie

DKB 512 - Spiritualiteitsvorming

DKB 532 - Preekvoorbereiding (Klaspreek)

DKB 542 - Liturgiese praktyk

DKB 553 - Pastorale berading

DKB 563 - Siekepastoraat

DKB 574 - Kerklied in die erediens

DKB 584 - Klaspreke

DKB 600 (6de jaar)

DKB 611 - Kerklied in praktyk

DKB 621 - Gemeente-ontwikkeling

DKB 632 - Missionaat

DKB 643 - Visuele verkondiging

DKB 684 - Klaspreke

In aanvulling tot die DKB modules word pastoraatmodules in basiese gespreksvaardighede, sterwensorg, rousmart en bejaardesorg vir vierdejaar BTh-studente aangebied. Modules in traumaberading en fasiliterende leierskap is toegevoeg tot die MDiv 1 se kurrikulum. Vir studente in MDiv 2 (finale jaar), wat ' $n$ jaar lank praktiese gemeentewerk doen, word kursusse oor lewensverryking, kerklike leierskap, vergaderingprosedure, diakonaat, die Nederduitsch Hervormde Sustersvereniging (NHSV) as diensorgaan, die kerklike argief en museum, kerklike administrasie en finansiële bestuur, die SA Bybelgenootskap en TV- en radiobediening aangebied.

Die HTK vier vanjaar sy vyftienjarige bestaan. Sedert die vestiging van die Kollege het dit van krag tot krag gegaan. Die meeste van die aanvanklike doelwitte is bereik. Prof. Dreyer het van 2000 tot 2011 die leiding geneem, dr. Christo van der Merwe van 2012 tot 2014 en dr. André Ungerer sedert 2015.

\section{Dr. Christo van der Merwe}

Jacobus Christiaan van der Merwe is op 11 Mei 1949 in Standerton gebore. Hy is die oudste van vyf kinders. Hy het 'n jonger broer en drie susters. Hy voltooi sy skoolopleiding in 1967 aan die Hoërskool Standerton en begin in 1968 met teologiese studie aan die Universiteit van Pretoria. Hy het aanvanklik, soos menige Hervormde predikante, in Huis Voortrekker tuisgegaan. Na die sluiting van Huis Voortrekker
DKB 500 (5th year)

DKB 511 - Sermon Strategies

DKB 512 - Spiritual Formation

DKB 532 - Sermon Preparation

DKB 542 - Liturgical Practice

DKB 553 - Pastoral Counselling

DKB 563 - Pastoral Care of the Sick

DKB 574 - Music and Liturgy

DKB 584 - Preaching

DKB 600 (6th year)

DKB 611 - Music and Liturgy

DKB 621 - Congregational Development

DKB 632 - Missional Practice

DKB 643 - Visual Media

DKB 684 - Preaching

In addition to the DKB modules, BTh 4 students take courses in basic conversational skills, care of the terminally ill, grief counselling and care of the elderly. Modules in trauma counselling and facilitating leadership were added to the MDiv 1 curriculum. For MDiv 2 students (the final year), who do a year-long internship in a congregation, there are courses on life skills, church leadership, meeting procedures, the diaconate, the Women's League of the NRCA as service organ, the church's archives and museum, congregational administration and financial management, the South African Bible Society, and TV and radio ministry.

The RTC celebrates its 15th anniversary this year. Since its establishment, the College has been developing and evolving. Most of the initial goals have been met. Prof Theuns Dreyer served as the Director from 2000 to 2011 and Dr Christo van der Merwe from 2012 to 2014. Currently, the position is filled by Dr André Ungerer.

\section{Dr Christo van der Merwe}

Jacobus Christiaan van der Merwe was born on 11 May 1949 in Standerton as the eldest of five children. He has a younger brother and three sisters. He completed his school education at the Standerton High School in 1967 and enrolled for theological studies at the University of Pretoria in 1968. He initially found accommodation in the Voortrekker Residence, as did many ministers of the NRCA, but when Voortrekker was closed, he moved to Marula. During the final year of his theological studies, he married Henela. They had two children, Kosie and Laurentia. Henela passed away in 1992. He subsequently married Rita who had two children, Nadine and Chantelle. For 10 years, Christo and Rita were foster parents to Dawid, a boy from a DPS Home (Children's Foster Homes of the NRCA). Dawid is currently 22 years old and still has regular contact with the family.

Christo van der Merwe was ordained on 12 January 1975 in the Newlands congregation of the NRCA, after which he served in Bulawayo from 1977, Newcastle from 1979 
word hy 'n inwoner van Huis Maroela. In sy finale jaar is hy met Henela getroud en twee kinders, Kosie en Laurentia, is uit die huwelik gebore. Henela is in 1992 oorlede. Tans is hy met Rita getroud. Haar twee kinders is Nadine en Chantelle. Christo en Rita het 10 jaar lank 'n seun, Dawid, uit 'n DPShuis (Diakonale Pleegsorg) in pleegsorg geneem. Dawid is nou 22 jaar oud en het steeds noue kontak met die familie.

Na sy legitimasie in 1974 word Christo van der Merwe op 12 Januarie 1975 in die gemeente Newlands georden. Hy aanvaar in 1977 'n beroep na die Bulawayo-kombinasie, in 1979 na Newcastle en in 1983 na Kempton Park-Oos waar hy tot 31 Desember 2011 as predikant dien. Hy bly tydens die 3 jaar van sy hoofskap van die HTK deeltyds by die gemeente betrokke.

Dr. Van der Merwe beskik oor besondere leierseienskappe. Die volgende hoogtepunte kenmerk sy breër diens in die kerk:

- In 1999 promoveer hy met'n proefskrif getitel, "n Praktiesteologiese evaluering van 'n gemeentebouprojek in die NH Gemeente Kempton Park-Oos vir 'n praktykmodel'.

- Etlike jare lank doseer hy gemeenteboupraktyk en missiologie by die HTK. Later, as hoof van die HTK, brei sy doseerverpligtinge uit.

- Hy volg verskeie kursusse in die fasilitering van gemeenteontwikkeling. Hy bied 10 jaar lank'n gevorderde kursus in gemeentebou by die Sentrum vir Kontekstuele Bediening by die UP aan. Hy is mede-aanbieder van kursusse in gemeentefasilitering en 'brugbediening' by die UP. Hy is dikwels by die Kerk se voortgesette teologiese toerusting betrokke.

- Hy fasiliteer by verskeie gemeentes ten opsigte van gemeentebou en konflikhantering.

- Hy volg verskeie kursusse in berading om sy terapeutiese en interpersoonlike vaardighede verder te ontwikkel. Hy is 'n gekwalifiseerde MBTI-praktisyn met 'n profiel van ENFP. Hy bedryf tans 'n spreekkamer vir terapie met volwassenes en doen huweliksberading.

- Hy doseer reeds meer as 'n dekade deeltyds by die Afrika Instituut vir Missiologie (AIM), die opleidinginstansie van die Maranatha Reformed Church of Christ (MRCC).

- Hy dien van 2001 tot 2004 in die Kommissie van die Algemene Kerkvergadering as predikantslid, van 2004 tot 2007 as vise-voorsitter en van 2010 tot 2013 as predikantslid.

- Hy dien as voorsitter van die Taakspan vir gemeentes en predikante en is deel van die paneel vir die versorging van pastoriegesinne.

- Rade en komitees waarin hy gedien het, sluit die volgende in: die Kuratorium, die Proponentseksamenkommissie, die Raad vir Apostolaat, die Raad vir Kategese, die Raad vir Prediking en Erediens, die bestuur van die Predikantevergadering (as sekretaris en voorsitter), die Komitee vir Missionale Gemeentes (as voorsitter), die Raad van Finansies, asook verskeie Ringskommissies (as skriba en voorsitter).

- Op ekumeniese terrein verteenwoordig hy die Kerk by die destydse Wêreldbond van Reformatoriese Kerke en die Gereformeerde Ekumeniese Raad in Utrecht, Nederland. and Kempton Park East from 1983 to 31 December 2011. He continued to serve there part-time after his appointment as Director of the College.

Dr Van der Merwe has excellent leadership qualities and served not only the congregations in which he worked but also the Church as a whole. Highlights of his involvement are the following:

- In 1999, he received a PhD from the University of Pretoria with a thesis entitled, 'A practical theological evaluation of the development project in the NRCA congregation of Kempton Park East for a model of practice'.

- For a number of years, he lectured in congregational development and missiology at the RTC.

- He took various courses in the facilitation of congregational development. For 10 years, he taught an advanced course in congregational development at the Centre for Contextual Ministry at the University of Pretoria. He co-taught courses in facilitation and 'bridge ministry' at the University of Pretoria. He often contributed to the continuing education programme of the Church.

- He facilitated congregational development and conflict management in various congregations.

- He attended various counselling courses to develop his therapeutic and interpersonal skills. He is a certified MBTI practitioner and his profile is ENFP. He currently runs a pastoral counselling practice for adults and does marriage counselling.

- For more than a decade, he lectured at the Africa Institute of Missiology (AIM), the institution for the theological training of ministers of the Maranatha Reformed Church of Christ (MRCC).

- He served in the Commission of the General Assembly, between 2001 and 2004 as member, between 2004 and 2007 as vice-moderator and between 2010 and 2013 as member.

- He served as chairperson of the Task Team for Congregations and Ministers and was a member of the panel responsible for the care of ministers and their families.

- He served in the Curatory, the Examination Commission, the Apostolate Council, the Council for Christian Education, the Council for Preaching and Worship, the Executive of the Ministers' Assembly (as scribe and chairperson), the Committee for Missional Congregations (as chairperson) and the Board of Finance. He served in various Circuit Commissions (as scribe and chairperson).

- On the ecumenical front, he represented the Church at the then World Alliance of Reformed Churches and the Reformed Ecumenical Council in Utrecht, the Netherlands.

- After retirement, he remained involved in the work of the College, with much dedication.

As a leader in the Church, Dr Van der Merwe often provided new direction in difficult times. His insights were inspiring, 
- Na die aanvaarding van sy emeritaat is hy steeds by die HTK betrokke en verrig die taak met groot toewyding.

As kerkleier dui dr. Van der Merwe dikwels in onsekere tye 'n nuwe koers aan. Sy insig in kerkwees is inspirerend en sy visie vir die toekoms bied 'n uitdaging aan die kerk. Vir kollegas is hy 'n steunpilaar, vertroueling en mentor. Hy is 'n geliefde pastor. As dosent is hy gewaardeer en gerespekteer onder die studente. Vir sy gesin is hy 'n anker en stille krag. Die Afrikaanse digter, Jan F. Celliers (1865-1940), se gedig oor die boeregeneraal, Christiaan de Wet, kan op Christo van der Merwe toegepas word.

Strofe 1 van die oorspronklike gedig:

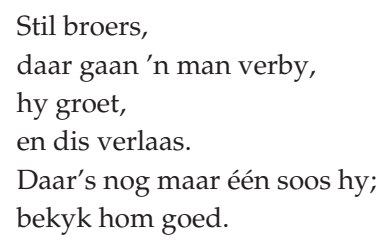

Met aanpassings aan Christo van der Merwe opgedra:

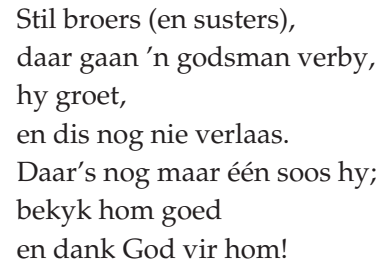

his vision a challenge to the church. He was a pillar of support, a confidante and mentor to colleagues. He was well-loved, much appreciated and respected by students. He is an anchor to his family. The poem about the Boer general, Christiaan de Wet, by the Afrikaans poet, Jan F Celliers (1865-1940), can be applied to Christo van der Merwe.

A translation of the first verse of the original poem (own translation):

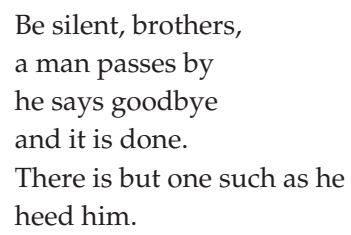

Amended and dedicated to Christo van der Merwe:

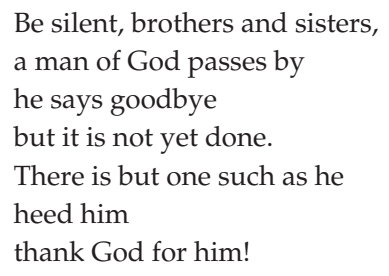

\section{Literatuurverwysings/References}

Nederduitsch Hervormde Kerk van Afrika (NHKA), Agendas van die 66ste tot 70ste Algemene Kerkvergadering van die Nederduitsch Hervormde Kerk van Afrika, Kerkargief.

Oberholzer, J.P., 2010, 'Honderd jaar kerk en teologiese opleiding: 'n Kroniek van die Hervormde Kerk', HTS Teologiese Studies/Theological Studies, Supplementum 9.

Opperman, D.J., 1980, Groot verseboek, Tafelberg Uitgewers, Cape Town. 


\section{Appendix 1}

\section{Curriculum Vitae: J.C. (Christo) van der Merwe}

Christo van der Merwe, born 11 May 1949, was appointed as head of the Reformed Theological College at the Faculty of Theology of the University of Pretoria in 2012. He is an ordained minister of the Netherdutch Reformed Church of Africa and served as a full-time minister of religion in four congregations between 1975 and 2011. He attained his DD in Practical Theology from the University of Pretoria in 2000. He is a qualified pastoral therapist in the following fields: MBTI accredited practitioner, adult therapy, marriage counselling, trauma counselling.

\section{Personal information}

Date of birth: 11 May 1949 in Standerton, South Africa Spouse: Rita

Children: Kosie, Laurentia, Nadine and Chantelle (foster child, Dawid) Grandchildren: Jolene, Stiaan, Luhan, Wihanro and Eddie

\section{University of Pretoria}

Baccalareus Artium: Greek, Hebrew and Philosophy (1971). Baccalareus Divinitatis: Theology (1974).

Doctor Divinitatis: Practical Theology, "n Prakties-Teologiese evaluering van 'n gemeentebouprojek in die Nederduitsch Hervormde Gemeente Kempton Park-Oos met die oog op die daarstelling van 'n praktykmodel' (2000).

\section{Courses developed and presented}

- Cathegesis, UP, final year

- Missional building of the local church, UP, final year

- Youthwork, UP, final year

- Church administration, UP, final year

- KITAL - courses at UP congregational administration, postgraduate

- Centre for contextual ministry, UP module V, building the local church, postgraduate

- Centre for contextual ministry, UP - bridge ministry: conflict handling, postmodernism, postgraduate

- AIM (Africa Institute for Missiology), UP accredited, youth work, second and final year

- AIM (Africa Institute for Missiology), UP accredited, building the local church and church administration, first year

- TEO 873, UP, final year

- VTT, RTC, postgraduate

\section{Minister of religion}

Minister of the Netherdutch Reformed Church (NRCA) Newlands (19751976), Bulawayo combination (1977-1978), Newcastle (1979-1982) and Kempton Park East (1983-2011).

\section{Published conference papers}

'Die Kerk se werk', conference of the Society of Practical Theology in South Africa - 1979 and 1980. pp 73-89, 'Die terrein van die kerklike diens van barmhartigheid'.

HTK opening-2009, 'Missional congregations'; published online in Deo Gloria.

\section{Books}

Van der Merwe, J.C. \& Steenkamp, P.L., 1982, Huweliksgeluk, KITAL, Pretoria.

\section{Chapters in books}

Van der Merwe, J.C., 2001, 'Kerkloosheid: Oorsake en moontlike oplossing', in J. Botha (red.), Ja vir Jesus Nee vir die Kerk, bl. 59-79, Lapa, Pretoria.

Van der Merwe, J.C., 2006, 'Al hoe meer om te gee...', in M. Nel (red.), Stories van Hoop: Gemeentes wat in hulle konteks ' $n$ verskil maak en hoop bring, pp. 135-152, Christelike Uitgewersmaatskappy, Vereeniging.

\section{Articles in peer reviewed journals}

Van der Merwe, J.C., 1997, 'Die missionêre gerigtheid van die kerk', HTS Teologiese Studies/Theological Studies 53(3), 705-721. http://dx.doi. org/10.4102/hts.v53i3.1690

Van der Merwe, J.C., 1999, "n Prakties-teologiese begronding vir gemeentebou as kommunikatiewe handeling in diens van die evangelie', HTS Teologiese Studies/Theological Studies 55(2/3), 380-399. http:// dx.doi.org/10.4102/hts.v55i2/3.1589

Van der Merwe, J.C., 2007, 'Die eenheid wat tussen Christene bestaan', Die Hervormer 100(6), 5-6.

Van der Merwe, J.C., 2011, 'Missionale gemeentes in die Nederduitsch Hervormde Kerk van Afrika: Teologies verantwoord', HTS Teologiese Studies/ Theological Studies 67(3), Art. \#1094, 9 pages. http://dx.doi.org/10.4102/ hts.v67i3.1094

Van der Merwe, J.C., 2012, "n Homilie oor geloofsonderskeiding in 'n akkoord van drie', HTS Teologiese Studies/Theological Studies 68(1), Art. \#1259, 8 pages. http://dx.doi.org/10.4102/htsv68i1.1259

Van der Merwe, J.C., 2013, 'Lense op spiritualiteit en kerkwees: Die pad vorentoe vir die Nederduitsch Hervormde Kerk van Afrika (NHKA)', HTS Teologiese Studies/Theological Studies 69 (1), Art. \#1988, 16 pages. http:// dx.doi.org/10.4102/htsv69i1988

Van der Merwe, J.C., 2014, "n Narratief vir kerk-wees vandag', HTS Teologiese Studies/Theological Studies 70(1), Art. \#2699, 13 pages. http:// dx.doi.org/10.4102/htsv70i.2699

\section{Popular scientific articles}

\section{Almanak}

Van der Merwe, J.C., 1994, 'Bestendige gesin', 88, 175-181.

Van der Merwe, J.C., 1997, 'Gemeentebou: Is ons regtig wie ons sê ons is?', 91, 138-140.

Van der Merwe, J.C., 2012, 'Huldeblyk: Ds CJ Janse van Rensburg 12-121942 tot 04-01-2011', 106, 202.

\section{Die Hervormer}

Van der Merwe, J.C., 1979, 'Terroriste-oorlog in Rhodesië. Aangeblaas deur verdagmaking en leuens', 71(8), 5-6.

Van der Merwe, J.C., 1995, 'Bedoeling van Predikantevergadering van 12 September 1995. Notule van die eerste vergadering van Hervormde predikante, 1924', 88(7), 8.

Van der Merwe, J.C., 2002, 'Klein gemeentes kan ook sterk gemeentes wees', 95(15), 1-3.

Van der Merwe, J.C., 2003, 'Kerk in die branding (2): Erediens 'n fees!', 95(20), 5.

Van der Merwe, J.C., 2004, 'Terug by die Wêreldbond', 97(12), 1-8.

Van der Merwe, J.C., 2005, 'Stories van hoop. Wat leer die gapingstorie ons? (2)', 97(21), 5.

Van der Merwe, J.C., 2005, 'Hoop vir 2005!', 97(19), 5. 
Van der Merwe, J.C., 2005, 'Stories van hoop. Wat leer die gapingstorie ons?', 97(20), 5 .

Van der Merwe, J.C., 2006, Redaksioneel. 'Here lewe! Lewe die kerk?', $99(2), 4$.

Van der Merwe, J.C., 2007, 'Stories van hoop: Kemptonpark-Oos. God bly besig met ons', 99(20), 5 .

Van der Merwe, J.C., 2007, 'Perspektief op ekumene: Eenheid wat tussen Christene bestaan', 100(6), 5.

Van der Merwe, J.C., 2008, 'Leef die opgestane Heer in en deur ons?', 101(1), 1.

Van der Merwe, J.C., 2009, 'Nuwe koers vir apostolaat', 102(2), 1.

Van der Merwe, J.C., 2010, 'Missionale gemeentes: Om deel te neem aan God se sending', 103(6), 1.

Van der Merwe, J.C., 2011, 'In Christus se voetspore', 104(8), 1.

\section{E-Hervormer}

Van der Merwe, J.C., 2010, 'Reus moet wakker word!', 3(11), 1.

\section{Konteks}

Van der Merwe, J.C., 1991, 'Jeug: Jongmens, evangelisasie is jou taak', 2(7), 30 .

Van der Merwe, J.C., 1992, 'Kleinjeug: Ouers as gawe van God', 3(3), 35.

Van der Merwe, J.C., 1994, 'Daar staan geskrywe: Waarom het Jesus die tempel gereinig?', 5 (1/2), 39.

Van der Merwe, J.C., 1994, 'Daar staan geskrywe: Matt 22:34-40; Markus 12:28-34; Lukas 10:25-37. Ou vraag: Wie is my naaste?', 5(3), 51.

Van der Merwe, J.C., 1994, 'Daar staan geskrywe: Psalms leer ons bid', 5(4), 10.

Van der Merwe, J.C., 1994, 'Daar staan geskrywe: Psalms - bron van geloofsversterking, troos en vreugde', 5(5), 36.

Van der Merwe, J.C., 1994, 'Daar staan geskrywe: Berou, belydenis en vergifnis in die Psalms', 5(6), 42.

Van der Merwe, J.C., 1994, 'Daar staan geskrywe: Woede en wraak in die Psalms', 5(7), 42.

Van der Merwe, J.C., 1994, 'Daar staan geskrywe: Efesiërs 6 10-20. Leer om met God se wapens te veg', 5(8), 42.

Van der Merwe, J.C., 1994, 'Daar staan geskrywe: Christen se wapenrusting. Waarheid as gordel om julle heupe', 5(9), 42.

Van der Merwe, J.C., 1994, 'Daar staan geskrywe: Die wapenrusting van God. Vryspraak deur God as borsharnas', 5(10), 42.

Van der Merwe, J.C., 1994, 'Daar staan geskrywe: Wapenrusting van God. Bereidheid om die evangelie te verkondig', 5(11), 42.

Van der Merwe, J.C., 1994, 'Daar staan geskrywe: Wapenrusting van God. Geloof as skild in die hand', 5(12), 42.

Van der Merwe, J.C., 2000, 'Heilige Gees en die jaar 2000', 11(6), 4-5.

Van der Merwe, J.C., 2007, 'Hi! Wmj? Kom ons leer by kerke in Afrika', 18(7), 14-15.

\section{Resensies en boekbesprekings}

1987, L. Floor, 'Lamp vir almal in die huis: Christelike leefreëls vir die huwelik, gesin en samelewing', HTS Teologiese Studies /Theological Studies 43(3), 629-632.

1989, B.J. van der Walt, 'My roeping as Christenjongmens in die huidige Suid-Afrika', HTS Teologiese Studies /Theological Studies 45(1), 217-222.

1990, M. Valenkamp, 'Sin van ons bestaan', HTS Teologiese Studies / Theological Studies 46(3), 475-476.

1994, A.J. Antonites, 'Regstellende aksie: Prinsipiële riglyne', HTS Teologiese Studies /Theological Studies 50(4), 1094

1995, P.L. Steenkamp, 'Woorde en note: Ons doop ons kinders', Konteks $6(10), 46$.

1997, J. Cilliers, 'Uitwissing van God op die kansel', HTS Teologiese Studies / Theological Studies 53(4), 1443-1444.

1997, I. Bria, 'Liturgy after the liturgy, mission and witness from an orthodox perspective', HTS Teologiese Studies /Theological Studies 53(4), 1452-1453.

1999, R.F. Capon, 'Foolishness of preaching: Proclaiming the gospel against the wisdom of the world', HTS Teologiese Studies /Theological Studies 55(1), 262-263.

2000, S. van Wyk, 'My dominee is hopeloos', HTS Teologiese Studies / Theological Studies 56(2/3), 854-855.

2001, B.J. van der Walt, 'Godsdiens en samelewing / Religion and society', in HTS Teologiese Studies /Theological Studies 57(3/4), 1365-1366.

2001, B.J. van der Walt, 'Naby God, Christen en Kerk op die drumpel van spiritualiteit', HTS Teologiese Studies /Theological Studies 57(3/4), 13661367.

2001, A. Ferreira, 'Eenmaal iets dappers', HTS Teologiese Studies / Theological Studies 57(3/4), 1367-1368.

2002, J.A. Kirk, 'What is mission?', HTS Teologiese Studies/Theological Studies 58(3), 1298

2002, J. Cilliers, 'Genade van gehoorsaamheid', HTS Teologiese Studies / Theological Studies 58(4) 1876-1877.

2004, A.B. Roninson, 'Transforming congregational culture', HTS Teologiese Studies /Theological Studies 60(4), 1537-1538.

2006, B. Gietz, 'Hammer of God', HTS Teologiese Studies/Theological Studies 62(2), 756-757.

2006, K. Anthonissen, 'Luister na die lig', HTS Teologiese Studies / Theological Studies 62(4), 1543-1544.

2007, C. Burger, 'Ontmoetings met die lewende God: Hoe God ons roep, nuut maak - en stuur', HTS Teologiese Studies /Theological Studies 63(4), 1736-1737.

2010, N.C.P. Frambach, 'Emerging ministry: Being church today', HTS Teologiese Studies /Theological Studies 66(1), 459.

2010, T. Loder, 'Loaves, fishes and leftovers, sharing faith's deep questions', HTS Teologiese Studies /Theological Studies 66(1), 469

2010, 'Q \& A Worshipping', HTS Teologiese Studies/Theological Studies 66(1), Art. \#995, 1 page. http://dx.doi.org/10.4102/hts.v66i1.995 